\title{
Effect of the complex improver on consumer properties of bakery products
}

\author{
Olena Bilyk, Esma Khalikova, Anastasiia Shevchenko, \\ Oksana Kochubei-Lytvynenko, Yuliia Bondarenko, Albina Fain
}

\author{
National University of Food Technologies, Kyiv, Ukraine
}

Keywords:

Improver

Bakery

Staling

Flavor

Dextrins

Freshness

\section{Article history:}

Received

16.07.2019

Received in revised

form 09.01.2020

Accepted

30.03 .2020

Corresponding author:

Olena Bilyk

E-mail:

bilyklena@

gmail.com

DOI:

$10.24263 / 2304-$

974X-2020-9-1-13

\section{Abstract}

Introduction. In order to improve the consumer properties of bakery products made using accelerated technologies, a study was conducted on the possibility of using a directional baking improver "Freshness +".

Materials and methods The consumer properties of the bakery product "Freshness" (from premium wheat flour, yeast, salt, margarine, white sugar) were investigated in the work. The technological process was carried out with the duration of the dough keeping - $20 \mathrm{~min}$ and the use of the "Freshness +" improver, which was dosed in the amount of $2.0 \%$ by weight of flour. The quality of the finished products was evaluated by physicochemical and organoleptic parameters.

Results and discussion The use of improver in amount of $2.0 \%$ by weight of flour increases the specific volume of products by $11 \%$, improves form resistance, porosity and reduces the fermentation time by three times, namely up to 20 minutes. This is due to the use of amylolytic enzyme improver in the composition, which contributes to the increase of gasforming and sugar-forming capacity. Product with improver preserves freshness, as evidenced by an increase in total crumb deformation by $26.0 \%$, a smaller subcutaneous layer and fewer air layers in the baking bundle for 72 hours without packaging. There is more accumulation of dextrins and bisulfite binders in the products when using the improver, which indicates the inhibition of the staling processes of the products and improvement of consumer properties. This is due to the fact that there are moisture-retaining additives in the products, namely maltodextrin and $\mathrm{p}$ gelatinized starch, which retain osmotic and adsorption-bound moisture during storage. Maltodextrin is also a water-soluble hydrocolloid that increases moisture retention and forms a three-dimensional network that inhibits the interaction of gluten and starch, resulting in retrograde of starch.

Conclusions. The use of the improver slows down the starch retrograde due to the formation of coagulated proteins from its constituents with flour during baking, in the middle of which there are swollen, often gelatinized starch grains, and increasing the amount of dextrose. 


\section{Introduction}

As a result of the staling of the baked goods, they lose the luster of the crust, the intensity of the taste and aroma, the softness and springiness of the crumb, and acquire considerable fragility. The deterioration of the consumer properties of bakery products is due to the transformation of the biopolymers of the products during storage, namely, the transition of starch from the amorphous state to the crystalline and loss of some water by protein [1].

For the simultaneous adjustment of the quality of flour, technological process and ensuring the lengthening of freshness of bakery products, it is advisable for manufacturers to use complex baking improvers [2, 3].

The range of complex baking improvers (CBI) is very diverse, depending on the direction of their action [3]. In general, complex baking improvers consist of different ingredients, namely gluten oxidizers and reducing agents, enzymes, emulsifiers and various food additives or ingredients with specific effects [4, 5, 6]. All components of complex baking improver are carefully selected due to their activity and synergistic effect [7]. Complex baking improvers act throughout the technological process and are designed for solving specific challenges.

The complex baking improver "Freshness + " is known for prolonging the freshness of bakery products made using accelerated technologies [8].

To extend the freshness of the bakery products, the Austrian company "Backaldrin" offers a comprehensive baking improver, "Winer Note", consisting of vegetable oil, sugar, skimmed milk powder, emulsifier, dextrose, salt, lecithin, ascorbic acid. The recommended dosage is from 1.0 to $10.0 \%$ by weight of flour. CBI "Winer Note" extends the shelf life several times [3]. This improver prevents moisture from condensing to preserve softness and freshness, but does not affect the intensification of the process.

A Dutch company "Zeelandia" offers a comprehensive bakery improver "Gamma Soft", which consists of soy flour, emulsifier, ascorbic acid, enzymes, to extend the freshness of bakery products [9]. A significant disadvantage of this improver is the use of soy flour, so it is advisable to study the use of improvers made from other non-traditional raw materials, namely dry mashed potatoes.

The French company "Lessaffre" recommends to use the complex baking improver "Mazhimix" with a white label for long-term storage products such as bread from wheat, bakery products and muffins in order to extend their freshness up to 2 months. It contains specially selected monoglycerides, which slow down the starch retrogradation process. The enzyme complex of this improver allows to obtain an additional amount of dextrins, whereby the pulp will retain its properties over time [10]. The disadvantage is that manufacturers keep a secret about the composition of a complex baking improver, in particular a complex of enzymes, so it is unclear whether its use will accelerate the technological process.

The authors of [11] recommend to use the composition of dry wheat gluten, an enzyme preparation of amylolytic action and a mixture of xanthan and guar gums in complex baking enhancers to prolong the freshness of bakery products. The developed improver extends the freshness of bakery products up to 72 hours of storage unpackaged. But the paper does not provide recommendations for its optimal dosage in the case of processing flour with different baking properties.

It is advisable to investigate the effect of the developed improver on the consumer properties of bakery products made using accelerated technology, where the fermentation stage is replaced by keeping.

The purpose of this work was to substantiate the feasibility of using the complex baking improver "Freshness +" to improve consumer properties of bakery products. 
To achieve this goal, the following tasks were formulated:

- To investigate the influence of the improver on the technological process and quality of bakery products;

- To study the effect of improver on the processes of staling of bakery products ";

- To investigate the influence of the improver on the aroma of bakery products.

\section{Materials and methods}

\section{Objects and materials}

The complex baking improver "Freshness +" includes: dry potato powder, enzyme preparation "Alphamalt VC 5000", maltodextrin, ascorbic acid.

The bakey product "Freshness" was made from premium wheat flour by an accelerated method:

- Premium wheat flour $-100 \mathrm{~kg}$;

- $\quad$ Pressed bakery yeast $-3.0 \mathrm{~kg}$;

- $\quad$ Salt - $1.5 \mathrm{~kg}$;

- Margarine $-2.5 \mathrm{~kg}$;

- White crystalline sugar $-2.5 \mathrm{~kg}$.

For development of the complex baking improver "Freshness +", dry potato powder, was used as the main filler. It is made according to the technology [19]. In terms of physicochemical parameters, dry potato powder complies with the requirements shown in Table 1.

Physico-chemical parameters of dry potato powder, $n=3, p \leq 0.95$

\begin{tabular}{|l|c|}
\hline \multicolumn{1}{|c|}{ Indicator } & Value \\
\hline Mass fraction of moisture, \% & 12.0 \\
\hline Mass fraction of protein, \% & 8.3 \\
\hline Mass fraction of mono-and dissacharides, \% & 3.3 \\
\hline Mass fraction of starch, \% & 74.5 \\
\hline Mass fraction of fiber, $\%$ & 6.6 \\
\hline Mass fraction of fat, $\%$ & 0.4 \\
\hline Mass fraction of insoluble in hydrochloric acid ash, \% & 3.5 \\
\hline Minerals, mg/100g: & \\
\hline Magnesium & 24.0 \\
\hline Potassium & 572.0 \\
\hline Calcium & 11.0 \\
\hline Phosphorus & 60.0 \\
\hline Sodium & 29.0 \\
\hline Water absorption capacity, $\%$ & 71.3 \\
\hline Autolytic activity, $\%$ of dry matter & 37.9 \\
\hline The degree of caking, $\%$, for the pore size of the sieve $-250 \mathrm{~nm}$ & 18.4 \\
\hline Whiteness, units & 90.5 \\
\hline
\end{tabular}


The dry potato powder according to whiteness corresponds to whiteness of wheat flour of the premium grade, has a low tendency to formation of lumps (the degree of caking did not exceed $3.0 \%$ ), therefore it can be used as a functional basis for complex baking improvers.

For the production of the complex baking improver the enzyme preparation "Alphamalt VC 5000" (5000 SKB/g) of the German company "Muhlenchemie" is used, maltodextrin of the Polish company, defatted lecithin from sunflower produced by the Ukrainian company "BIOLER" and ascorbic acid produced in China are used.

\section{Methods of research of the quality of bakery products with a complex baking improver}

Method of laboratory baking for research of the quality of bakery products. Laboratory baking was carried out to investigate the indicators of the technological process, biochemical, physico-chemical changes in the dough and qualitative indicators of bread. The dough was prepared in an accelerated manner with a moisture content of $43.5 \%$. The dough was kneaded in a two-speed dough mixing machine. Keeping time was $30 \mathrm{~min}$. The dough was processed manually, perseverance of the dough pieces was carried out in a thermostat at a temperature of $(38 \pm 2)^{\circ} \mathrm{C}$ and relative humidity $(78 \pm 2) \%$ until readiness. The products were baked in an oven at $220-240{ }^{\circ} \mathrm{C}$.

Bread quality was evaluated by physical and chemical (specific volume, shape resistance, structural and mechanical properties of crumb) and organoleptic parameters (appearance, crust surface condition, porosity structure, taste, smell).

Method of research of total deformation for investigation of the duration of storage of freshness of products. The duration of storage of freshness of products was investigated by changes in the structural and mechanical properties of the crumb. Its total deformation after $48 \mathrm{~h}$ of storage was determined with the use of penetrometer AP 4/1 [12].

The area of the subcutaneous layer was determined organoleptically by changing its stiffness and crumb. The transition between the subcutaneous layer and the crumb was circled by a marker [13].

Method of research of microscopy of bakery products. Microscopy of bakery products was carried out after $4 \mathrm{~h}$ of baking and at the end of storage, ie after $72 \mathrm{~h}$ of storage. The samples were stored unpackaged at $(20 \pm 0){ }^{\circ} \mathrm{C}$. Samples were prepared by freezing, lyophilic drying and spraying in a vacuum chamber of carbon on a piece of dried sample. The samples were examined using the electron scanning microscope "IEOLJSMM - 200" at a magnification of 1000 times and the photos of the most visible sections were taken.

Method of research of content of dextrins. The content of dextrins was determined by the method of their mass fraction, which is based on the ability of dextrins to precipitate at different concentrations of ethyl alcohol in solution. Samples were inactivated by enzymes to release them from water-soluble carbohydrates, digestion of sugars for their extraction, precipitation of dextrins with solutions of alcohol of different concentration, dissolution of recovered dextrins with water and hydrolysis with $2 \%$ hydrochloric acid, determination of the amount of glucose in the hydrolyzate of dextrins of different molecular weight by the method of Wiltter and Schudl. On the basis of the determined content of dextrins the mass fraction of dextrins was determined by fractions, depending on the mass fraction of dextrins at different concentrations of ethyl alcohol [14]. 
Method of research of moisture bond in the dough. Determination of the moisture bond in the dough was performed by thermogravimetry using a " $\mathrm{Q}-1000$ " derivatograph in the temperature range of $20-200{ }^{\circ} \mathrm{C}$ at a rate of heating of samples weighing $1.00 \mathrm{~g}-1.25$ ${ }^{\circ} \mathrm{C} / \mathrm{min}[15]$.

Method of research of the content of flavoring substances in bread. The content of flavoring substances in bread was inferred by the amount of bisulfite binding compounds determined by the method $[12,20]$.

\section{Results and discussion}

\section{Investigation of the effect of the improver on the process and the quality of bread}

The obtained results due to laboratory baking were compared to those obtained by straight dough process. The dosage of the improver was $2.0 \%$ to weight of flour, the duration of dough keeping was 20 minutes. The obtained results were compared to those obtained by straight dough process. A sample prepared according to the recipe above without improver was as a control sample. The results of the study are given in Table 2.

The analysis of the results of the research shows that the time spent on fermentation of semi-finished products with the addition of the improver is three times less, compared to their production by traditional technologies. The use of the improver increases the specific volume by $11 \%$, the porosity and improves the form resistance of finished products. The researcher improves the freshness of bakery products by $26.0 \%$.

It was established that the use of the improver helps to reduce the duration of the technological process and increase the specific volume of bakery products. This is due to the use of amylolytic enzyme which is in the improver, which increases the gas-forming and sugar-forming capacity.

\section{Investigation of the effect of the improver on the process of staling of bread}

The difference in organoleptic characteristics between the crumb and the crust is the result of baking processes when the surface is exposed to higher temperatures than the crumb. Baking creates a relative moisture gradient and moisture content between the crust and the crumb, which causes the redistribution of moisture in the product. This causes the softness of crust, staling of crumb, form a thicker subcutaneous layer during storage. Therefore, it was advisable to investigate the effect of the improver on the area of formation of the subcutaneous layer (Figure 1). 
Table 2

Influence of the improver on technological process and product quality, $n=3, p \leq 0.95$

\begin{tabular}{|c|c|c|}
\hline \multirow{2}{*}{ Indicator } & \multicolumn{2}{|c|}{ Bakery product } \\
\hline & Control sample & Sample with the improver \\
\hline \multicolumn{3}{|c|}{ Dough } \\
\hline Mass fraction of moisture, $\%$ & \multicolumn{2}{|r|}{43.5} \\
\hline Duration of fermentation, min & 210 & - \\
\hline Duration of keeping, min & - & 20 \\
\hline Duration of proofing, $\min$ & 40 & 35 \\
\hline Acidity, degrees & 1.0 & 1.0 \\
\hline initial & 1.8 & 1.4 \\
\hline \multicolumn{3}{|c|}{ Finished products } \\
\hline \multicolumn{3}{|l|}{ Organoleptic characteristics: } \\
\hline Correctness of form & $\begin{array}{l}\text { Oval, slightly vague, the } \\
\text { cuts are clear }\end{array}$ & $\begin{array}{l}\text { Oval, not vague, the cuts are } \\
\text { clear }\end{array}$ \\
\hline Color of the crust & \begin{tabular}{|c|} 
Light \\
\end{tabular} & From golden to brown \\
\hline State of the surface of the crust & $\begin{array}{l}\text { Smooth enough, single } \\
\text { small bubbles, barely } \\
\text { noticeable small short } \\
\text { cracks and blasts, glossy }\end{array}$ & $\begin{array}{c}\text { Impeccably smooth, free } \\
\text { from bubbles, cracks, blasts, } \\
\text { glossy }\end{array}$ \\
\hline Porosity structure & \multicolumn{2}{|c|}{$\begin{array}{c}\text { The pores are small, thin-walled and medium-sized, } \\
\text { evenly distributed }\end{array}$} \\
\hline Flavor & \multicolumn{2}{|c|}{ Intensely pronounced, relative for bread } \\
\hline Taste & \multicolumn{2}{|c|}{ Intensely pronounced, relative for bread } \\
\hline Specific volume, $\mathrm{cm}^{3} / 100 \mathrm{~g}$ & 330 & 367 \\
\hline Form resistance, $\mathrm{h} / \mathrm{d}$ & 0.39 & 0.44 \\
\hline Porosity, $\%$ & 80 & 86 \\
\hline Acidity, degrees & 1.8 & 1.4 \\
\hline \multicolumn{3}{|l|}{$\begin{array}{l}\text { Total crumb deformation, units } \\
\text { of penetrometer }\end{array}$} \\
\hline in: $\quad 4 \mathrm{~h}$ & 82 & 102 \\
\hline in: $\quad 72 \mathrm{~h}$ & 46 & 84 \\
\hline Preserving of freshness, $\%$ & 56 & 82 \\
\hline
\end{tabular}

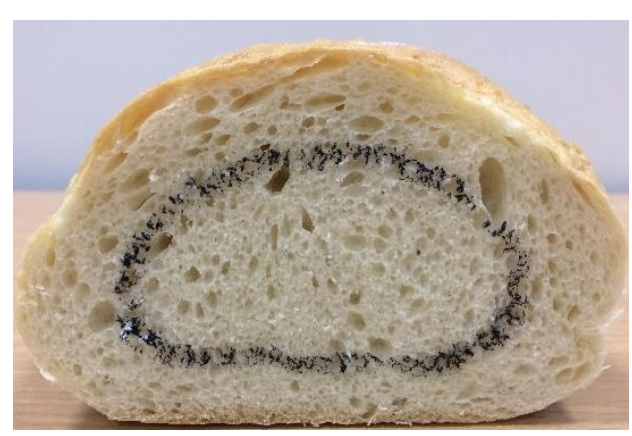

Control sample

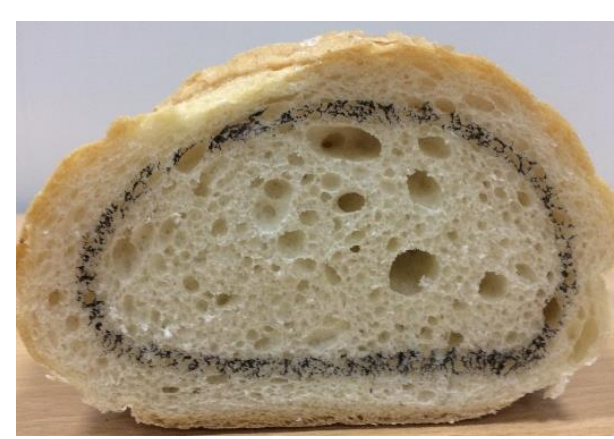

Sample with the improver

Figure 1. Formation of a subcutaneous layer during the baking process after $72 \mathrm{~h}$ of storage 
The results of the studies show that during the storage process, using developed improver the subcutaneous layer of the bakery product is smaller after $72 \mathrm{~h}$ of storage, compared to the subcutaneous layer of the control sample.

Further studies were concerned with the microscopic examination of the bakery product during storage. The results of the studies are shown in Figure 2.

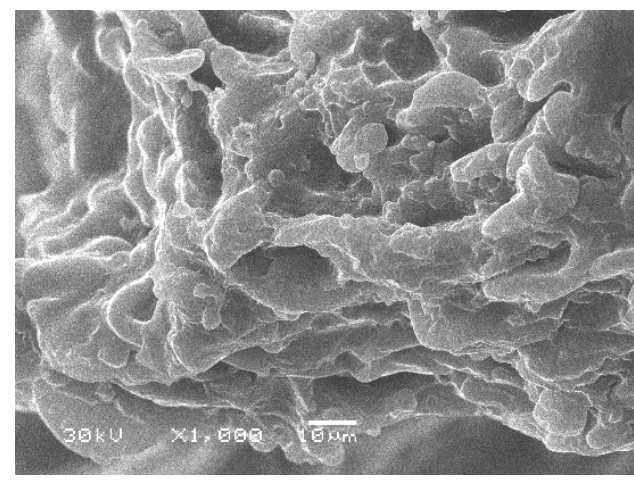

Control sample

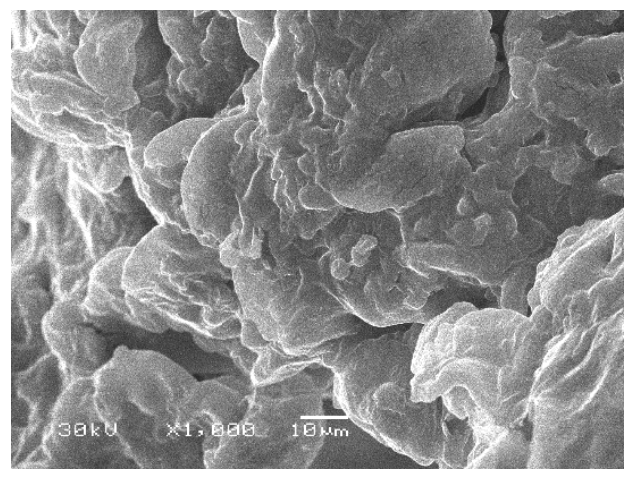

Sample with the improver

Figure 2. Microstructure of the crumb of bakery products after 72 hours of storage

The bread crumb structure is characterized by the presence of pores that are wrapped around by the interstitial walls that create a spongy frame. The control sample has layers of air in the interstitial walls under the microscope, indicating a decrease in the volume of starch grains due to the formation of the crystalline structure of starch. The crumb of the product with the improver consists of a whole mass of coagulated proteins during the baking process, in the middle of which partially glistened starch grains are swollen, and only in some places there are visible layers of air.

The lengthening of freshness is caused by the introduction of moisture-retaining additives, namely maltodextrin and gelatinized starch, which contain osmotically and adsorbed bound moisture during the storage of the products with the improver. Maltodextrin is also a water-soluble hydrocolloid that increases the degree of moisture retention and forms a three-dimensional net that inhibits the interaction of gluten and starch, resulting in retrograde of starch $[16,17]$.

It has been found that the use of the improver reduces the formation of a subcutaneous layer, improves the crumb structure in the case of keeping the loaf for 72 hours without packing.

During the baking process, the destruction of starch occurs, and amylolytic enzyme and maltodextrin are introduced into the dough with the improver, so it was expedient to investigate the change in the amount of dextrins in bakery products. Dextrins were determined after $4 \mathrm{~h}$ of cooling. The results of the studies are presented in Table. 3. 
Content of dextrins in bakery products, $n=3, p \leq 0.95$

Table 3

\begin{tabular}{|l|c|c|c|c|}
\hline \multirow{2}{*}{$\begin{array}{c}\text { Samples of } \\
\text { bakery products }\end{array}$} & \multicolumn{2}{|c|}{ Content of dextrins by fractions, \% to dry matter } & \multirow{2}{*}{$\begin{array}{c}\text { Total content } \\
\text { of dextrins }\end{array}$} \\
\cline { 2 - 4 } & Amylodextrins & Erythodextrins & $\begin{array}{c}\text { Malto- and } \\
\text { achrodextrins }\end{array}$ & \\
\hline Control sample & 0.968 & 0.402 & 0.908 & 2.278 \\
\hline $\begin{array}{l}\text { Sample with the } \\
\text { improver }\end{array}$ & 1.387 & 0.428 & 1.678 & 3.493 \\
\hline
\end{tabular}

In the case of the use of the improver, there is a significant increase in dextrins - by $55.3 \%$ compared to the control sample due to the presence of $\alpha$-amylase in the improver, the introduction of additional oligosaccharides with dry potato powder and directly maltodextrin. In this regard, the process of staling of bakery products is slowed down by the formation of a three-dimensional net by low molecular weight dextrins, which impedes the interaction of gluten and starch and the yield of moisture by starch $[13,18]$.

Literature sources show that the ability of bakery products to maintain freshness is related to the content of bound water [15]. Therefore, it was necessary to determine the content of bound and free water in the crumb. The determination was performed using derivatograph. The analysis of thermogravimetric curves made it possible to obtain quantitative characteristics of the distribution of moisture in the crumb of products with additives and to change its state during storage (Figure 3 ).

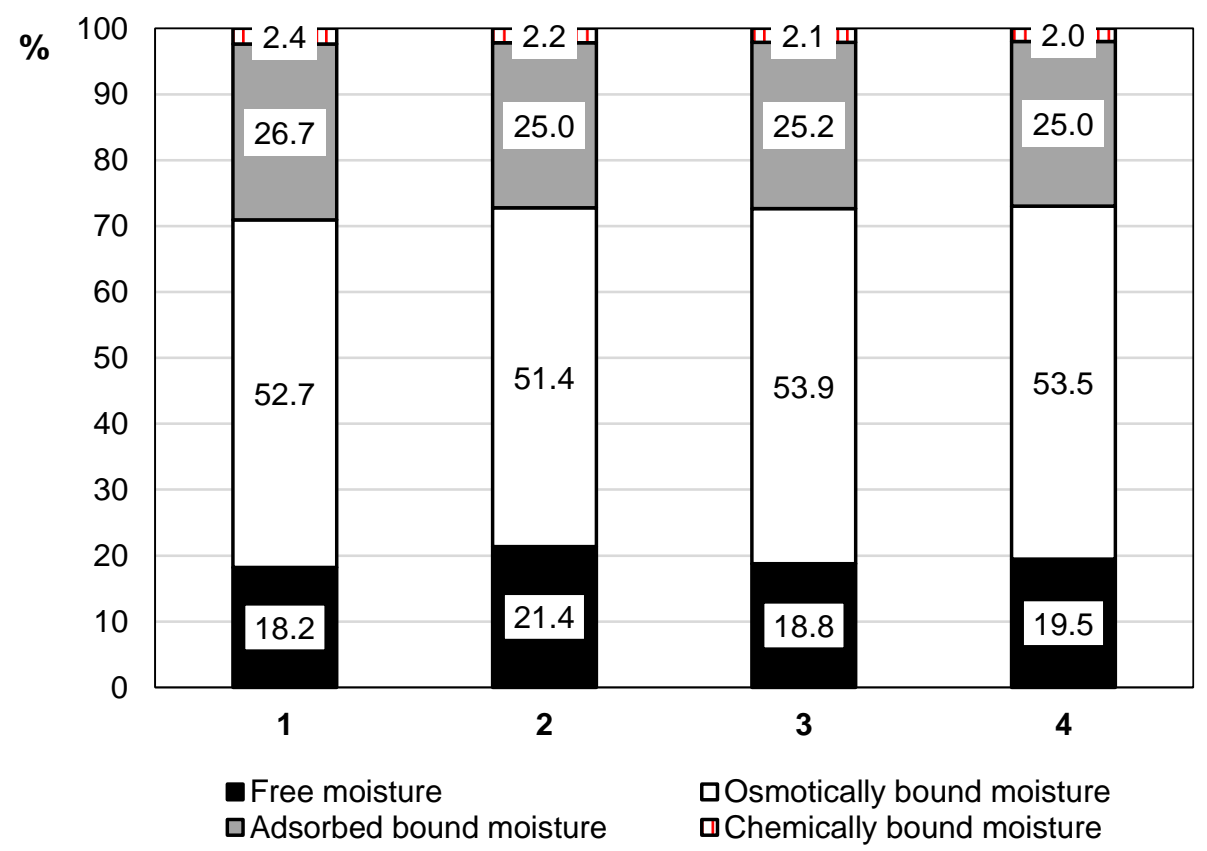

Figure 3. Changes in moisture bounds in the samples of products during storage:

1 - control sample after 24 hours; 2 - control sample after 72 hours;

3 - sample with the improver after 24 hours; 4 - sample with the improver after 72 hours. 
At the first stage of removing moisture from the samples of bread, there is its significant loss. In this temperature range, free moisture, moisture contained in macro- and microcapillaries, and immobilized water is removed. The total amount of this moisture in the samples of products is $18.2 \%$ of the total weight of water for the control sample during the first day of determination, and $18.8 \%$ of the total weight of water in the product for the sample with the improver. On the fourth day of storage of products, the moisture content of these forms of bond for the control sample increases by $3.2 \%$ of the total weight of water in the product, and for the product with the improver - by $0.7 \%$ of the total weight of water in the product.

The second and third temperature intervals correspond to the endothermic peak, that is, in these ranges endothermic processes occur, which may be related to the removal of moisture with significant binding energy, obviously, osmotically and adsorbed bound water. As it can be seen from Figure 3 the amount of osmotically bound moisture is higher than in the control sample and is $53.86 \%$ of the total weight of water in the product. After four days of storage, the amount of osmotically bound moisture in bread with the improver is slightly reduced, but remains greater than in the control sample. The amount of adsorbed bound water during the first day of storage and after four days of storage is almost the same.

The fourth temperature interval corresponds to the removal of chemically bound water. As it can be seen from the analysis, the content of this water in the samples is increasing, but it is very small compared to other forms of bonding moisture.

During the study at the end of storage, it was found that samples of products tended to decrease osmotically and adsorbed bound moisture and to increase the free moisture and moisture of microcapillaries, but this reduction is less with the improver.

Therefore, the results of the analysis of the moisture bond in the samples of the products with the improver suggest that the slowing of staling of these samples is associated with a lower content of free moisture, macro- and microcapillaries at the beginning of storage and an increase in the amount of osmotically bound moisture [13]. This correlates with the obtained data to determine the total deformation of the crumb.

\section{Investigation of the effect of the improver on the aroma of bread}

Consumer and nutritional value of products depend on organoleptic quality indicators, namely aroma.

The effect of the improver on the content of carbonyl compounds in the finished products are shown in Table 4.

Thus, the introduction of the improver to the products increases the content of bisulfite binding compounds, compared to the control sample, by 1.3-4.1 times, despite the duration of storage. Increasing the content of carbonyl compounds in finished products with additives correlates with improved crust color and bread aroma.

When adding the improver to the dough, the content of carbonyl compounds in the crumb and crust of the bakery products increases. This is because of the fact that the improver contains an enzyme preparation of amylolytic action, which accelerates the process of persistence and separation of more carbonyl compounds. The increase in the content of bisulfite binding compounds is further explained by the fact that the improver includes maltodextrin, which, along with the slowing of the staling, accelerates the fermentation process. 
Content of bisulfite binders, eq. $\mathrm{mg} / 100 \mathrm{~g}$ of bread, $\mathrm{n}=3, \mathrm{p} \leq 0.95$

\begin{tabular}{|l|l|l|}
\hline Selection area & Control sample & Sample with the improver \\
\hline \multicolumn{3}{|c|}{ After 4 hours } \\
\hline Crumb & 6.8 & 27.9 \\
\hline Crust & 7.6 & 31.1 \\
\hline \multicolumn{3}{|c|}{ After 24 hours } \\
\hline Crumb & 5.5 & 22.6 \\
\hline Crust & 6.3 & 26.1 \\
\hline \multicolumn{3}{|c|}{ After $\mathbf{4 8}$ hours } \\
\hline Crumb & 4.6 & 5.6 \\
\hline Crust & 18.7 & 24.4 \\
\hline \multicolumn{3}{|c|}{ After $\mathbf{7 2}$ hours } \\
\hline Crumb & 3.3 & 4.6 \\
\hline Crust & 13.2 & 18.8 \\
\hline
\end{tabular}

Therefore, the use of the improver helps to extend the freshness of the bakery products up to 72 hours of storage unpackaged.

However, the impact of the improver on the mechanism of loss of moisture during storage remains unclear.

Further studies will be aimed on the impact of the improver on biological activity, the degree of digestion of proteins of bakery products and on selection of packaging materials for their storage.

\section{Conclusions}

1. It was found that the use of the improver in the amount of $2.0 \%$ by weight of flour using the accelerated technology of bakery products leads to an increase in the volume, improve the form resistance and porosity and reduce the fermentation process to 20 minutes.

2. The use of optimum dosing of the developed improver prolongs the storage time up to 72 hours without packaging. This is evidenced by an increase in the total deformation of the crumb, a decrease in the subcutaneous layer and a smaller number of layers of air in the crumb, as well as a greater accumulation of dextrins in the products.

3. It was established that in case of the use of the improver, the number of bisulfite binding compounds increases, which has a positive effect on the aroma of bakery products, which is less removed during storage compared to the control sample.

\section{References}

1. Kwasnievska-Karolak I., Rosicka-Kaczmarek J., Krala L. (2014), Factors influencing quality and shelf life of baking products, Journal on Processing and Energy in Agriculture, 18(1), pp. 1-7.

2. Ibrahim U., Salleh R., Maqsood-ul-Haque S. (2015), Bread towards Functional Food: An Overview, International Journal of Food Engineering, 1(1), pp. 39-43. 
3. Alsuhaibani A. (2018), Rheological and Nutritional Properties and Sensory Evaluation of Bread Fortified with Natural Sources of Calcium, Journal of Food Quality, pp. 1-7.

4. Renzetti S., Delcour J., Arendt E. (2010), Oxidative and proteolytic enzyme preparations as promising improvers for oat bread formulations: Rheological, biochemical and microstructural background, Food Chemistry, 119(4), pp. 1465-1473.

5. Moayedallaie S., Mirzaei M., Paterson J. (2010), Bread improvers: Comparison of a range of lipases with a traditional emulsifier, Food Chemistry, 122(3), pp. 495-499.

6. Joye I., Courtin C., Delcour J., Decamps K. (2012), Glucose and pyranose oxidase improve bread dough stability, Journal of Cereal Science, 55(3), pp. 380-384.

7. Tebben L., Shen Y., Li Y. (2018), Improvers and functional ingredients in whole wheat bread: A review of their effects on dough properties and bread quality, Trends in Food Science \& Technology, 81, pp. 10-24.

8. Bilyk O., Khalikova E., Hryshchenko A., Marynin A. (2016), Vykorystannia kompleksnoho khlibopekarskoho polipshuvacha «Svizhist +» u tekhnolohii bulochnykh vyrobiv, Naukovi pratsi NUFT, 22, pp. 233-242

9. Krist R. (2011), Sozdavat vozmozhnosti, Hleb+vypechka i konditerskie izdelija, 2, pp. 32-35.

10. Tanasiichuk B., Mieshkov Yu. (2020), Shliakhy podovzhennia tryvalosti zberihannia khliba, Visnyk KNTU, 1(72) 135, p. 140.

11. Lazovenko I., Stenycheva N. (2015), Ispolzovanie fermentnyh preparatov v sostave kompleksnogo uluchshitelja dlja sohranenija svezhesti hleba, Trudy BGTU. Himija, tehnologija organicheskih veshhestv i biotehnologija, 4, pp. 198-201.

12. Drobot V. (2015), Tekhnokhimichnyi kontrol syrovyny ta khlibobulochnykh $i$ makaronnykh vyrobiv, Kondor, Kyiv.

13. Bhise S., Kaur A. (2014), Baking quality, sensory properties and shelf life of bread with polyols, J Food Sci Technol, 51(9), pp. 2054-2061.

14. Kurek M., Wyrwisz J. (2015). The Application of Dietary Fiber in Bread Products, $J$ Food Process Technol, 6(5), pp. 1-4.

15. Nilova L., Kalinina I., Naumenko N. (2013), Metod differencialno-termicheskogo analiza v ocenke kachestva pishhevyh produktov, Vestnik JuUrGU. Serija «Pishhevye i biotehnologii», 1, pp. 43-48.

16. BeMiller J. (2009), One hundred years of commercial food carbohydrates in the United States, Food Chem, 57, pp. 8125-8129.

17. Onyango C. (2016), Starch and modified starch in bread making: A review, African Journal of Food Science, 10(12), pp. 344-351.

18. Baratto C., Becker N., Gelinski J., Silveira S. (2015), Influence of enzymes and ascorbic acid on dough rheology and wheat bread quality, African Journal of Biotechnology, 14(46), pp. 3124-3130.

19. Gjore Nakov, Viktorija Stamatovska, Ljupka Necinova, Nastia Ivanova, Stanka Damyanova (2015), Sensor analysis of functional biscuits, Ukrainian Food Journal, 5(1), pp. 56-62.

20. Carlos K., Dejager L. (2017), Determination of Sulfite in Food by Liquid Chromatography Tandem Mass Spectrometry: Collaborative Study, Journal of AOAC International, 100(6), pp. 1785-1794. 